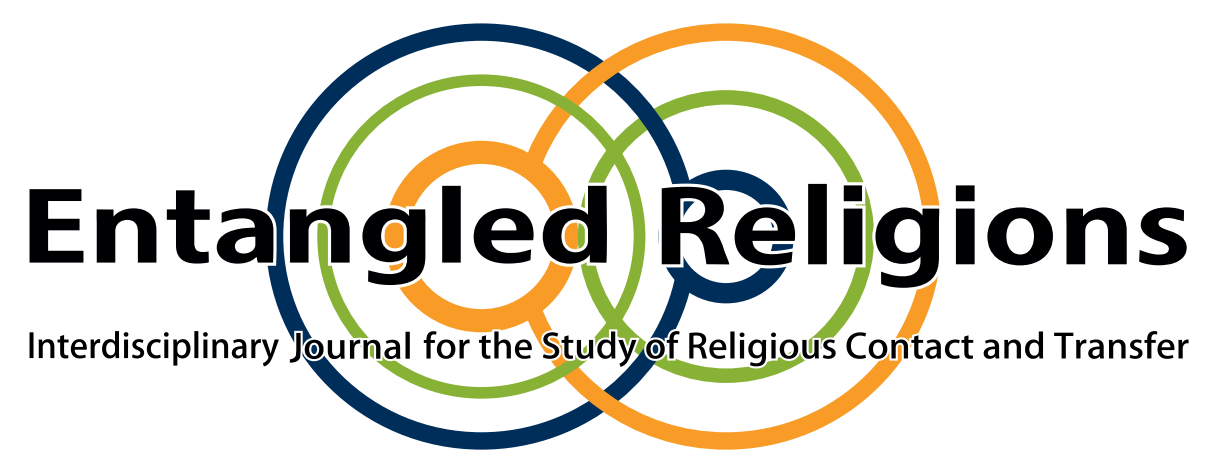

\title{
Introduction: (How) Do We Share the Sacred?
}

MANFRED SING

Leibniz Institute of European History, Mainz, Germany

This contribution to Entangled Religions is published under the Creative Commons Attribution 4.0 International Public License (CC BY 4.0 International). The license can be accessed at https://creativecommons.org/licenses/by/4.0/legalcode.

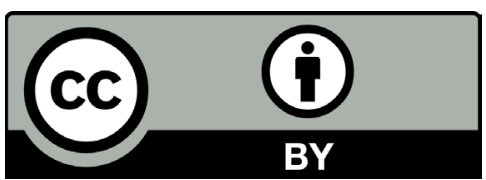

Entangled Religions 9 (2019) http://doi.org/10.13154/er.v9.2019.3-33
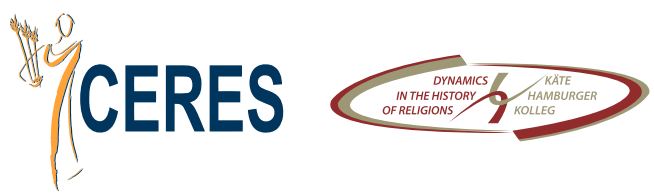

SPONSORED BY THE 


\title{
Introduction: (How) Do We Share the Sacred?
}

\author{
MANFRED SING \\ Leibniz Institute of European History
}

\begin{abstract}
Multi-religious cohabitation bears immense social and political implications, since the question of how multi-religiosity should be organized has become a hotly debated topic all over Europe. Although religious diversity has turned into an everyday experience in many parts of the world today, a perception that understands conflict between religions as inevitable still holds sway and has maybe even grown stronger, especially after violent events such as the terror attacks of 9/11 and the recent upsurge of political populism in Europe and the Americas. A historically informed perspective that illustrates the widespread dissemination of religious mixture and the commonness of religious interaction throughout the centuries, however, may help us to see current debates in a different light. The present focus edition is dedicated to this purpose.
\end{abstract}

KEY WORDS shared sacred places; inter-religious encounter; polemics; room; place; space

\section{Introduction}

Places and events shared by adherents of different faiths are by no means historically exceptional; on the contrary, they are well documented for Asia, Europe, and Africa, and are no less characteristic for the three monotheisms around the Mediterranean basin (see e.g. Albera 2008; Couroucli 2012). The historiography and anthropology of such phenomena not only challenges the ascription of a singular religious identity to sacred places and religious events; it also questions simple narratives about the relation between the religious monopoly on truth and multi-religious cohabitation, understood as either functioning smoothly or stillborn. Thus, while some scholars in the social sciences believe that political stakeholders nurture religious conflicts, others hold the opposing view that if such conflicts are socially constructed, then inter-religious spaces, expressing religious toleration, can and should also be established.

Obviously, however, there is no automatism either for violent conflict or for peaceful coexistence. Therefore, it seems appropriate in the studies of multi-confessional and multi-religious spaces to leave the "either-or" logic behind and rather proceed from a middle ground that directs attention to the possible richness and diversity of examples and the paradoxical "interplay of sharing and competition, tolerance and antagonism, 
mixed worship and the destruction of other's shrines" (Albera 2008, 40). If we talk about shared sacred places, the ambivalent expression "shared" already hints at the fact that wherever people do something together or have something in common, there are simultaneous processes of distinction, demarcation, and division at work.

As religious competition and religiously legitimized violence have occupied academics as well as policymakers for quite some time now, a focus on place and space also seems a way to foster a better understanding of the underlying dynamics. As space, and especially sacred space, is a limited resource, the allocation of space between different groups is likely to be highly contentious, not only in land-scarce circumstances but also in secular ones, when competing claims to the use of spaceand the visibility of this use-are laid by different religious or secular actors.

This introduction gives a short overview of the historiography and anthropology of shared religious places and practices and spells out the knowledge interest of the present volume in relation to the wider field of research. I start with discussing the challenges of multi-faith rooms in contemporary societies and non-religious environments-an issue that most readers are certainly aware of, as it pops up regularly in the media. I then move on to the historiography of shared religious sites more generally and explain how the contributions of the current volume pick up on some of the main topics that have been treated by scholars in the field. After that, the underlying theoretical concepts of place, space, and the sacred are discussed in relation to recent scholarly debates. In the next two sections, some of the earliest historical examples of sharing and polemics between the three monotheistic religions as well as examples of not sharing are presented; these examples are meant to give a more complex picture of multireligious cohabitation. After this overview, the focus of the present volume will become clearer, which is to discuss changing inter- and trans-religious practices against the background of changing religious, cultural, and political landscapes. The authors' aim is to contribute to a complex and more comprehensive picture of the multiplicity of crossreligious relations and their historical transformations. For this purpose, this special issue of Entangled Religions brings together articles that approach the subject from different angles and disciplinary backgrounds-history, art history, Byzantine Studies, Eastern European and Ottoman Studies, Islamic Studies, anthropology, and sociology. The collection of these contributions aims to take stock of the research results of the last two decades, sum them up, discuss them in new light, reflect on them theoretically, and move in new directions. 


\section{Multi-Faith Rooms in a Non-Religious Environment}

A case that demonstrates the complexities of religious sharing is the installation of multi-faith rooms, which has become the norm even in many non-religious environments-in hospitals, retirement homes, prisons, schools, universities, shopping malls, exhibitions centres, train stations, and airports. Some scholars, such as Groß (2000), believe that there will be a growing demand for multi-faith rooms due to growing global mobility, giving rise to inter-cultural encounters, and a growing longing for oases of tranquillity against the noisiness of daily routine and the commodification of public space. Often, however, such rooms do not exactly fulfil the purpose for which they were built but create new challenges for those who go in and those who stay out. Muslims in European cities often find they do not get exactly the prayer room for which they had campaigned. The problem mostly stems from the fact that multi-faith rooms try to integrate religious diversity into a previously non- or mono-religious institution.

Re-structuring an already existing room, institutions often tend to favour one of four solutions in order to signify religious openness: universalization, emptiness, hiding, or parcelling (see Nagel 2015). Each of these solutions creates other difficulties, since they reconcile diversity with religious feelings in different ways. The first solution, the representation of the symbols of all major religious traditions, can hardly include all minorities and may irritate some believers who possibly feel disturbed by "rivalling" symbols. Therefore, this option is primarily adopted by avowedly multi-religious initiatives, like the Houses of Religions in Hannover and Bern, which have been founded through the cooperation of adherents from seven and eight faiths, respectively (e.g. Hauck-Hieronimi 2015). The second option, the radical abandonment of religious symbols-although creating religiously neutral places-easily fosters a feeling of incompleteness and risks leaving all believers equally unsatisfied. The third option, to move partition walls inside a room or illuminate certain parts of it according to one's own wishes, is not only a complex matter prone to error, but becomes even more intricate in simultaneous use. The subdivision into clearly designed parcels, if possible at all, often happens within a construction that is clearly identifiable as originally Christian or non-religious and thus often reflects a provisional nature. All four solutions integrate religious equality, symbols of specific religious cultures, religious minorities, and non-denominational groups to a different degree.

The result of these difficulties can best be observed at international airports, where different rooms for prayer, recreation, meditation, and relaxation-variously called multi- or inter-religious-co-exist. The first prayer rooms at airports were not inter-religious. A first-Catholic_chapel was opened at Boston Airport in 1951. In 1967, care for airport chapels was institutionalized by the foundation of the International 
Association of Civil Aviation Chaplains (IACAC). Starting in the 1980s, some of the chapels were transformed into inter-religious arrangements (Justnik 2008). From an anthropological point of view, it appears paradoxical that airports, as paradigmatic "non-places" (Augé 1995) which serve as areas of transit, not of interaction, should accommodate places where people of different faiths and cultures are supposed to meet.

Frankfurt Airport, for example, is not only a transit area but also the biggest local workplace in Germany, with 80,000 employees working for 500 companies and institutions. In 1969, the first chapel was opened at the airport (Beinhauer-Köhler and Meyer 2015, 195); in 1972, rooms for Catholic and Protestant airport chaplain services were installed. ${ }^{1}$ In the 1980 s, Fraport-the company which operates Frankfurt Airportdecided to expand the facilities for prayer rooms, and since then, the availability of such rooms has been increasing and diversifying in the publicly accessibly terminals as well as in the transit areas. Today, Frankfurt Airport offers nine prayer rooms for Christians, Jews, and Muslims, as well as two religiously neutral "Quiet Rooms," two yoga rooms, and several areas with "silent chairs" sealed behind noise-reducing glass-probably the most diverse ensemble of prayer and meditation possibilities in an airport worldwide. ${ }^{2}$

The establishment of rooms for praying as well as pastoral and social services was neither simply religiously motivated nor does it primarily aim at inter-religious exchange; Fraport must balance economic and pragmatic considerations when responding to spiritual, social, and psychological needs. At the end of the day, such rooms aim at the success of the airport's operations and the satisfaction of passengers and employees (Beinhauer-Köhler and Meyer 2015, 197f.), and can contribute to the locational advantage of the airport. Therefore, the arrangement of prayer and meditation rooms at the airport is not fixed but subject to constant changes that result from a spatial and economic dynamism affecting the airport as a whole (ibid., 198). Although the four main prayer rooms were accommodated side by side in a long and dreary corridor in the public area of departure Hall B in Terminal 1 (ibid., 195) for several years, this inter-confessional and inter-religious arrangement finally came to end in February 2019. The Orthodox room has definitively been closed. The Jewish room has been moved to departure Hall C, where it is easily locatable and accessible close to the check-in counters that operate El Al flights. And a new, circular, and much bigger Muslim prayer room has been opened in Hall E of Terminal 2, where an adjacent "Room of Quiet" is also located. Even the remaining ecumenical chapel will be relocated in the corridor that faces a complete renovation. Thus, the official inter-religious activities

1 Author's interview with the Catholic airport chaplain Heinz Goldkuhle SAC, 17 January 2019.

2 Author's interview with Fraport's diversity manager Christian Meyer, 17 January 2019. 
are now basically reduced to the annual festival of the "Abrahamic religions" that was established in 2001 as a reaction to 9/11 and consists of common prayers, speeches, music, and food at a lively point in the airport, the transition area to the train station.

As the institutionalization of the three monotheistic religions at the airport follows a different pattern, their presence and representation is also different, although all of them offer regular prayer times for passengers and workers. The staff of the Protestant and Catholic churches is deeply involved in the social and psychological services at the airport, including care for people in need of help, deportees, refugees, and surviving dependants. For Jewish matters, the rabbinate in Frankfurt city is responsible. The organization of Muslim prayer times and a calm operation during Ramadan or Hajj season is delegated to a Muslim employee of Fraport. Earlier counselling with DiTiB, the Turkish-Islamic Union for Religious Affairs (ibid., 200), has been terminated by Fraport to avoid inciting intra-Muslim, ethnic, or political rivalries. ${ }^{3}$ The example shows that in such a non-religious environment, religions are not wholly self-sustained entities but that Fraport plays the role of the "landlord," controlling the religious services that are offered inside its facilities and trying to restrict activities that may disturb daily routines.

Religiously neutral rooms at airports are located in a very different practical and symbolic context. The clientele and function of the so-called "Quiet Rooms" are more dubious than the purpose of traditional prayer rooms. Some are understood as interreligious places, like the rooms at Munich Airport and Vienna Airport, and some as religiously neutral, like the two rooms in Frankfurt Airport. Although some "Quiet Rooms" are consecrated during inauguration, as was the case in Munich and Vienna in 2005 and 2008, respectively (Löffler and Nikitsch 2008), they normally do not offer worship services but rather address individual and non-denominational travellers. In an atmosphere created by pleasant lighting, warm colour effects, and universal symbols made of wood, stone, or water, the rooms' aim is to encourage visitors to linger, no matter whether they stay for prayer and meditation or simply imbibe the silence. The model for this kind of room is a small meditation chamber at the United Nations headquarters in New York, called "Room of Quiet," which is characterized by a rhombic shape, dim light, an abstract painting, and a heavy block of iron ore from Sweden, put in the middle of the room. Opened in 1957, it was planned and supervised during construction by General-Secretary Dag Hammarskjöld (d. 1961), who had made the room his personal project. In a kind of manifesto, he explained that the room is meant to symbolize the universal longing for peace and harmony, independent of the viewers' faith and origin (Kletke 2000; Kuschel 2010, 5-7). It is certainly an ironic turn that this 
iconic multi-religious and multi-cultural room-that embodies the UN's foundational credo in such a simple, yet vivid form-is neither signposted nor part of the guided visitor tours; as a result, visitors who do not know of its existence will hardly find it (Kletke 2000, 98).

The yoga rooms at Frankfurt Airport form yet another category of spiritual rooms. Fraport advertises them in a video in which you can watch "FRAnky"-a human robot, dressed as an airplane-taking the escalator to a yoga room with a yoga mat under one of his wings and then finally performing parts of the sun salutation in one of the rooms. The message reads, "Get your yin back into the yang at Frankfurt Airport's free yoga rooms."

Such examples of "inter-religious" rooms for inner reflection, but without pastoral service and religious community, raise the question of how far they imitate or even parody religion in order to create the impression of representing a sacred place without being one (Jonas 2008). More critically, the question arises whether such rooms re-enact the extinction of historical places: they exemplify the expectation of the modern subject to emancipate herself from local and historical conditions and positively relate to de-localization and de-historicization (Spiegel 2008). Implicit in such a view is an ideological understanding of secularism and religion which assumes that peaceful inter-religiosity can only take place in spaces stripped of their local tradition and religious history. It is not that the airports, which also offer spaces for traditional religions, would openly subscribe to such a "philosophy." However, the exhibition of the photo artist Andreas Duscha (Justnik and Feldhoffer 2008), who took pictures of multireligious rooms in international airports on all continents, reveals an assemblage of sometimes carelessly arranged and sometimes over-designed spaces, thus reflecting an absurd organization of religious and cultural juxtaposition, fragmentation, and meaninglessness (Spiegel 2008, 19; Kölbl and Duscha 2010). ${ }^{5}$

The collection of the following articles is rather dedicated to an opposed approach. It traces the local and historical rootedness of cross-religious encounters connected to specific places, figures, and festivities. On the one hand, it shows the endurance as well as the constant transformations of multi-faith practices and landscapes throughout history. On the other hand, it indicates that the modern construction of inter-religious rooms grapples with new challenges, but also similar difficulties visible in historical examples of commonly used sacred sites. In this respect, multi-religious initiatives

4 See https://www.frankfurt-airport.com/en/travel/transfer.detail.suffix.html/service/at-the-airport/ yoga-rooms.html. Accessed February 1, 2019.

5 See a selection of his photos on his website https://www.andreasduscha.com/Places-of-Worship. Accessed March 22, 2019. 
in secular societies can certainly learn a lot from diverse examples of multi-religious cohabitation studied by historians and anthropologists.

\section{The Historiography and Anthropology of Shared Sacred Places}

The British historian and archaeologist Frederick W. Hasluck (1878-1920) is credited as one of the most important pioneers of research about what he called "ambiguous sanctuaries." He drew attention to the interplay of Christianity and Islam in his publication Christianity and Islam under the Sultans in 1929, posthumously edited in two volumes by his wife Margaret Hasluck (1885-1948). Before the publication of this work, the Haslucks had travelled in Asia Minor, Greece, and the Balkans regularly since 1904. Among other things, Frederick Hasluck studied commonly venerated saints, such as Khidur and Sarı Saltuk, and pointed at processes of Islamization behind superficially mixed religious practices. His pioneering role and influence has recently been confirmed by a series of essays critically re-evaluating his work, published in three volumes by the anthropologist David Shankland (2013).

As Tijana Krstic (2013) argues in one of Shankland's volumes, the reception of Hasluck's work followed a somewhat weird trajectory. Hasluck had pointed out that the "apparent equality" between Christianity and Islam in Bektashi shrines or in figures such as Sarı Saltuk was "only superficial” (Krstic 2013, 252). He also held that the ultimate aim of the Bektashi inter-religious activities in the Balkans "was not to amalgamate Christianity with Bektashism on equal terms, but to absorb Christianity into Bektashism" (ibid.). In spite of this, Hasluck's work became "inextricably intertwined with the discourse of syncretism" (ibid., 249) throughout the twentieth century. Hasluck's study entitled "Ambiguous Sanctuaries and Bektashi Propaganda" became particularly "emblematic" (ibid., 251) in this regard, not only as "primary example of syncretism" (ibid.) but also for the thesis that proselytizing antinomian "heterodox" dervishes had been the main agents of Islamization in Anatolia and the Balkans. Although Hasluck never used the word "syncretism" (ibid.), scholars referencing him contributed to the spread of the word in Ottoman studies at a time when it was increasingly falling out of use in the studies of religion (ibid., 247).

The lasting impact of Hasluck's work is visible in the fact that in this special issue, several authors pick up on questions raised by Hasluck and his successors. Stefan Rohdewald critically discusses the inter-religious aura ascribed to the saintly figure of Sarı Saltuk. Méropi Anastassiadou-Dumont points at the "Islamization" of sacred Christian places in contemporary Istanbul that were formerly visited by both 
Christians and Muslims but have become mainly Muslim due to the dwindling presence of Greeks. Dionigi Albera and Manfred Sing continue the theoretical debate about orthodoxy, heterodoxy, and syncretism by proposing new concepts to approach religious diversity-"polytropy" and "multi-religious topology."

David Shankland's (2013) volumes in honor of Hasluck bear testimony to the fact that academic interest in inter-religious sharing has increased in the last two decades, maybe as a reaction to popular prejudices about religious violence or violent religions. Recently edited volumes treat phenomena connected with inter-religious encounters with different foci and from various disciplinary backgrounds. From a background in the studies of religion, Beinhauer et al. (2015) analyze contemporary, multi-religious spatial arrangements in Western European societies. From a background in anthropology and the studies of religion, Albera and Couroucli (2012) deal with shared sacred places in the Mediterranean region, while Darieva et al. $(2017 ; 2018)$ focus on the Caucasus and Bowman's (2012) volume covers a wide range of regions from the Balkans to Nepal. Harris et al. (2012) as well as Barkan and Barkey (2014b) approach the same subject from a historical point of view and share an interest in the historical emergence of multi-religious spaces in areas of the Byzantine and Ottoman Empires.

One of the major questions in these volumes is why and when religious sharing turns into intolerance and violence. The anthropologist Robert M. Hayden has provided one of the most discussed answers to this question. In an article published in April 2002, he coined the telling terms "antagonistic tolerance" and "competitive sharing," which he later elaborated further (Hayden 2015, 2016). According to him and his followers, the sharing of holy places, though it seems to be a widespread practice, is no act of equality and permanence but only represents a transitional truce between two or more antagonistic groups-a temporal moment in which they realize that they are each unable to overcome the other. In this model, the dominant group only accepts the presence of other groups as long as it cannot expel them. Although subordinated groups are permitted to use a shared site, this is far from equal democratic sharing and only expresses both strategic acquiescence and latent conflict. Hayden (2002, 219) concluded that "diversity seems best to thrive under conditions that deny democracy (thus preventing the imposition of the will of the majority group) or display clear subordination of one group to another." Referring to contemporary Bosnia, he remarked, "attempts to impose diversity after a country has been partitioned may well require indefinite occupation to deny power to the nationalists for whom people would vote if given the chance to do so" (ibid.).

Hayden's article exemplifies that the academic interest in holy places is, like holy places themselves, not disentangled from contemporary issues. Hayden's take on "religious sites in South Asia and the Balkans" was very much framed through his focus 
on violence in the Jugoslav wars and "ethnic cleansing" in Bosnia in the 1990s (ibid., $205,213,214,216,219)$. Although the text draws from intellectual history as far back as John Locke, it seems more suggestive to assume that the author also re-thought his earlier research and came up with his "discomfiting" (ibid., 219) analysis under the impact of $9 / 11$, although this is not mentioned. The framing of shared sacred sites versus religious violence is by no means an exception. Barkan and Barkey (2014a, 2), for example, formulate four variations of the question of how to understand violence and conflicts "in such sacred settings" in their introduction of their edited volume.

Such a framing runs the risk of nurturing different problematic assumptions, such as the idea that monotheistic religions claim an exclusive monopoly of truth and must therefore be intrinsically violent and unable to share holy sites. Such assumptions also fit well with Huntington's (1996) thesis of the "clash of civilizations." Another problematic conclusion drawn from this framing could be a dichotomy between practices of sharing and the will of not sharing, although there is a multiplicity of forms of exchange and various degrees of interaction at shared sites, including "open conflict, antagonism between groups, uneasy coexistence, amiable mutuality, and forms of syncretism" (Barkey 2014, 46). Glenn Bowman, who has critically contributed to the debate about "antagonistic tolerance" since its beginning (Bowman 2002), revisits the debate and his contribution to it in this volume and puts it in a wider political context. He critically discusses the detrimental and self-fulfilling effects of discourses that turn identities into exclusive properties: "Sharing, or even mixing, is there rendered contentious, and local events in which individuals with different allegiances clash come to be read more widely as indubitable signifiers of irresolvable antagonisms."

Maybe the strongest objection to the model of an "antagonistic tolerance," in which cohabitation represents only a transitional phenomenon, is the historical argument that shared practices and sites existed for centuries, in spite of political, social, and violent ruptures-such as the rise and fall of empires, migratory movements, conversions, conquests, and wars-, in spite of the transition from colonial to post-colonial conditions, and in spite of nationalist or atheist state policies. There is ample evidence that numerous shared sites and pilgrimages survived even in the face of adverse conditions. However, it would also be one-sided to overlook these adverse conditions, visible in the forced conversion of sacred monuments. Barkey $(2014,53 \mathrm{f}$.), drawing on Bryer (1979), gives the decreasing numbers of monasteries that came under Seljuk, Ottoman, and Turkish rule as an example: Out of 417 urban monasteries known within the borders of the Byzantine Empire in the twelfth century, 80 still existed at the eve of the Ottoman conquest, 20 remained after 1453, and 6 continued to modern times. In the rural case, of the 283 rural monasteries, 158 existed on the eve of the Ottoman conquest, 91 survived after, and 62 continued into the modern period. 
These numbers reveal a complex trajectory that is extremely uneven between urban and rural areas. Under the same conditions, the percentage of urban monasteries fell to 1.4 percent of the amount in the twelfth century, while it was still at 21.9 percent in rural areas after eight centuries; this means a fifteenfold difference. Although the decrease in monasteries does not directly relate to shared sites but rather to a generally changing multi-religious space, the numbers fit Ora Limor's $(2007,231)$ assumption well that

to the extent that the holy site in question is more institutionalized and closer to the centre of religion, and to the extent that the tradition represented there is more central to the structure of the faith, exclusivity will be emphasized and border-lines more sharply marked. A syncretistic ritual is feasible at sites more remote from the geographical, institutional, and ideological centre, and it may be reviewed as 'grass-roots' religious phenomenon, rooted in the needs of the believers.

\section{Place, Space, and the Sacred}

The contributions in this volume are based on the presupposition that "place" and "space" form neither mere containers nor contexts for human action. Rather, space and human action are interwoven; just as human action produces and changes space, space structures and limits human action. Multi-religious sites are not only points of intersection in space and time where different religious dimensions have survived; they are also places in which social and religious struggles take shape or are contained, thus negotiating the meaning and limits of multi-religiosity. A closer look at the possibly ambivalent character of sacred places throws new light on one of the most prominent issues in the studies of religion, the relation between the "place" and the "sacred." According to the historian of religion Mircea Eliade (1907-1986), the sacred place is sharply distinct from its profane counterpart and forms the solid centre of the world (axis mundi), to which the believers' bodies, hearts, and minds are oriented (Eliade 2008, 23-62). In such a place, the sacred breaks through, appears in the profane, and becomes what Eliade calls "hierophany;" such a manifestation of the sacred suspends the relativity of profane place and allows human communication with the sacred.

New approaches in the study of religions question Eliade's sharp distinction between the sacred and the profane and are more interested in the "human processes" that contribute to the sacralisation of space. While Eliade's understanding is one-dimensional, social constructivism stipulates that nothing is inherently sacred. Accordingly, human actions constitute one place as profane and another as sacred. 
The question is how the inventors, architects, holders, and adherents of sacred places ascribe and inscribe meaning to places (Knott 2005a, 2005b, 2009). Place is produced, claimed, and negotiated by groups with specific interests; in the words of Jonathan $Z$. Smith $(1987,28)$, "Human beings are not placed, they bring place into being." Such constructivist approaches pay particular attention to rituals and practices that sacralise and politicize places and mark them as neither exchangeable nor negotiable. These approaches look beyond locally rooted, clearly marked, mono-religious sacred "places" and move on to "spaces," which are understood as more open, fluid, and dynamic. They add not only a diachronic and synchronic extension in time and space to sacred places, but also stress the physical, social, and symbolic dynamism in which these places are embedded. Political power shifts, while religious struggles over meaning and social mobility affect sacred places. Therefore, the structure, shape, use, and perception of sacred places not only reflect their religious dimension but also interact with changes in the political, social, and symbolic landscape. According to these scholarly approaches, sacred places are framed as ever changing, similar to religions, which are also not seen as fixed sets of elements but as an ever-evolving web of meanings, signs, and images. In this context, the scope of sacred places that are studied has also expanded; beyond official religious sites, attention is payed to unofficial places of worship in which religious practices take place (Knott 2005a, 2005b, 2009).

Against this background, the discussion on the multi-religious dimension of sacred places increases the focus on the constructed character of holy places because holiness, in a multi-religious context, is open to multi-dimensional meanings. The practices at multi-religious sites often show a dialectic between social openness and boundedness. The common use of sacred places often goes hand in hand with a porosity of boundaries and a re-erection of demarcations. In this respect, multireligious places show different degrees of interaction, regulation, competition, and contestation, partly depending on whether they are isolated shrines in rural areas or parts of sacral or non-religious building complexes in urban centres.

For mixed religious practices, a marginal location is often, but not always, characteristic because many of these practices take place on the margins of religious institutions or outside spaces that are directly controlled and overseen by the authorities, which may frown at certain practices that bring together and mix believers from different confessions or religions (Albera 2008). The local sharing of sacred places often does not follow top-down policies but is embedded in everyday experiences in which the religious Other is the neighbour (Bowman 2012). Not only places, but also saints and rituals can be shared and bear different layers of meaning. Looking at mixed religious practices on the margins leads to understanding religion beyond institutionbased constraints, closer to the ground, to the individual practitioners and their local 
identities. However, it would be wrong to see all cases of religiously "shared" places as examples of blurring boundaries or subversive acts directed against the authorities. If we bring in religious and political authorities beyond the local level, we discover that their roles differ widely. Sometimes they try to purge places of the religious Other; sometimes they are neutral or open to diversity; sometimes they support or even impose multi-religious practices (Weltecke 2012). Often enough, rulers exploit or even stage multi-religious practices in order to legitimatize their rule; if political fortunes change, multi-religious presentations can be discredited, may fall into oblivion, and can be supressed (ibid.).

In spite of the "spatial turn" in the academic discussion of place, the differences between place and space should not be blurred. Sociologist Thomas Gieryn (2000), pleading for "a space for place in sociology", names three defining features of placelocation, material form, and meaningfulness - that distinguish it from the surrounding, more inclusive and abstract space. Thus, inter-religiously shared place and multireligious space are different categories and must be kept distinct. Neither can multireligious space be reduced to examples of shared sites, nor do shared places symbolize a multi-religious landscape. Instead, a shared place represents a special arrangement for the direct encounter of different people, whereas multi-religious space can include different places, various arrangements, and contradictory behaviour. Although shared sacred places and multi-religious space are inter-connected in various ways, transformations on one of the two spatial levels often affect the other only indirectly. All contributions in this volume-although taking different examples as starting points and drawing on different theoretical approaches-highlight this difference between place and space as well as the pertinacity of the local versus the global.

Different religious groups not only share places simultaneously; sometimes, sharing is a serial and involuntary act. Since Late Antiquity, the de-sacralisation of temples, churches, mosques, and synagogues has concurred with the sacralisation of these buildings by new owners. Such cases of consecutive use are often controversialvisible, for instance, in the conversion of the Mesquita-Cathedral in Cordoba, the cathedral Santa María de la Sede with the Giralda in Seville (a former Almohad mosque), the Hagia Sophia in Istanbul, and in the destruction of the Babri Masjid in Ayodhya in 1992. A less prominent example is the Ibn Shushan Synagogue in Toledo. Built in the twelfth century in white colour and Moorish style influenced by Byzantine architecture, it was turned into a monastery named Santa María la Blanca after the Reconquista in the fifteenth century. Although a national memorial site and a museum still in the possession of the Catholic Church, it is no longer in religious use but has become an armoury of a company which produces bullfight swords. In 2013, more than 600 years after its conversion, the President of Jewish Communities in Spain made a 
request, unsuccessful as of yet, to return the building to its original owners. Though desacralized, the location is not like any other place but has somehow retained traces of its former sacred aura that, though absent, can be restored (given the request). In this case, sacredness connects past, present, and future; it stems, on the one hand, from the Jewish awareness that the location has a sacred history and, on the other hand, from the potentiality that it can be re-made sacred by human action-by returning it to its "original" use.

In his study of the conversion of 50 mosques to churches on the Iberian Peninsula after the so-called Reconquista, Arera-Rütnek (2017) distinguishes different steps of the transformation process that became increasingly systematized in the course of time. Often, Muslims were allowed to use the mosque for some years after the Christian conquest of a given town between the eleventh to the fifteenth centuries; then, sometimes as a reaction to Muslim uprisings, the Christians adopted, slowly transformed, and consecrated the mosque and thus officially turned it into a church. The phase of what Arera-Rütnek (2017, 22-59) calls "acculturation" introduced a new spatial organisation of the interior as well as the establishment of an altar and other symbols. While "acculturation" was accomplished by minor changes to the building, like turning the minaret into a bell tower with a cross on top, the further transformation process consisted of large-scale structural interventions which in some cases began as late as 100 to 300 years after the conquest (ibid., 58, 148-152). These interventions changed the shape and appearance of the whole complex by the introduction of a choir, chapels, and a church nave as well as through the modification of the former mosque courtyard (șahn) and the reconstruction of the bell tower. Sometimes, these works led to a completely new building after some centuries, so that it has become extremely difficult and sometimes even impossible to identify the original Islamic components. Curiously enough, however, many Iberian mosque complexes were built on the sites of early Christian churches.

Once a site has acquired holy status, its sanctity often adheres to it, "irrespective of political and religious vicissitudes," as Limor $(2007,219)$ states, remarking that "nowhere else, perhaps, is this rule more applicable than in the Holy Land." Over the past two thousand years, the country changed hands repeatedly. During the first millennium, it passed from Jewish to pagan rule, then became Christian and Muslim. In the second millennium, "it was successively Muslim, Christian, again Muslim, and finally Jewish" (ibid.). This development has not left sacred places untouched and has created tensions, especially in Jerusalem, which is sacred to all three religions. Several places in and around Jerusalem-most prominently the area of the Temple Mount-are venerated by members of more than one religion, yet, "only rarely has the sharing of traditions become a foundation for dialogue and amity," as Limor (ibid.) states. "For 
the most part, it has become a bone of contention; dialectically, in fact, the greater the similarity and the reciprocity, the greater the argument, rivalry, and competition, each group of believers straining to confirm its own exclusivity and prove its absolute right to the tradition and the holy place" (ibid.).

Beyond these examples, there are unproblematic, yet peculiar cases of consecutive sharing, such as the Brick Lane Mosque in London with its migration history. Founded in the eighteenth century as a Protestant church by Huguenots from France, it turned Methodist in the beginning of the nineteenth century and became a synagogue by the end of nineteenth century, when Jewish refugees from Russia and Eastern Europe populated the quarter. Finally, textile workers from Bangladesh bought and refurbished it and turned it into a mosque in the 1970s (Norwich 2011, chap. 53).

If we take a longue durée perspective, we find that sharing sacred places, although rather widespread, was and is unevenly distributed in different regions at different times. Put simply, one could say that from the fourth to the nineteenth centuries, the coexistence between Muslims, Jews, and Christians was more pronounced in the Southern and Eastern Mediterranean region than in Western Europe, because the Byzantine, Seljuk, and Ottoman Empires "were multi-confessional political constructs and were culturally less homogeneous than their Western counterparts" (Couroucli 2012, 2; c.f. Barkey 2014, 46-58). The overall picture only started to change during the nineteenth and twentieth centuries, when "traditions of mixing and sharing began to disappear" (Couroucli 2012, 3) as ideas of nationalism were imported and many nation-states attempted to build homogenous societies and were unwilling to organize religious pluralism (Barkan and Barkley 2014a, 3). Nationalist "efforts to impose a singular religious or ethnic order" (ibid.) resulted in various projects of homogenization "stretching from accommodation and assimilation to violence, expulsion, and genocide" (ibid.). Thus, a much-cited "culprit" for the politicization of religious difference is nineteenth-century nationalism, which often had a negative impact on religious sharing. In their contributions in this volume, Méropi Anastassiadou-Dumont, Stefan Rohdewald, Tanja Zimmermann, Glenn Bowman, and Dionigi Albera expose the impact of nationalism in different settings.

In contrast, Western European societies become less homogenous religiously and culturally since World War II, mainly because of migration and the influx of people from former colonies. On the one hand, the number of mixed neighbourhoods has grown in Western European cities; on the other, newcomers have often been placed on the margins, which is symbolically expressed by all the mosques that have been built in industrial zones. Yet again, this form of marginalization does not express insignificance. Quite on the contrary, the integration of Islam and Muslims into Western European societies has become a permanent topic of discussion. From Salman Rushdie's Satanic 
Verses in 1988/89 to the twelve caricatures of Muhammad in the Danish newspaper Jillands-Posten in 2005, Western European societies were also forced to rethink the meanings and limits of blasphemy and sacrilege.

Against this background, the use of the terms "sacred" and "holy" and their relation to "religious" and "profane" are by no means self-explanatory. Rather, these terms cover a complex and ambivalent field of meanings, especially if we talk about different, and internally differentiated, religions like Christianity, Judaism, and Islam. The ritual theorist Ronald L. Grimes $(2014,258)$ explains the appropriateness of the terminology in the following way:

Most of us intuitively understand that a synagogue, mosque, or a cathedral is in some sense sacred regardless of how Judaism, Islam, or Christianity theologically conceptualize space. If nothing else, such places are sacralised behaviourally. People comport themselves differently in them as they move from outside to inside or from front to back.

In this sense, ritual place is a location where the ritual occurs, but when the ritual stops, the place may either turn back into an ordinary place or remain extremely important. Although rituals are always placed, not all ritual spaces are connected to sacred places or remain permanently so. Some rituals lose their value if not performed in the right place or the right direction, while for other rituals space is merely incidental because the action matters, not its location. Yet even rituals that are directed to God or a transcendental force necessarily happen in a location. Therefore, "place matters even to people who adhere to creeds that say it doesn't" (Grimes 2014, 257).

Often the sacred character of a place becomes manifest more clearly by acts of de-sacralisation. Islamophobic attackers often use pork to express their rejection of everything Islamic and distribute it, for example, on building plots for mosques; although the mere act of deposing pork constitutes an act of swinishness, it would be far-fetched to consider it sacrilegious from an Islamic point of view. However, three people who attached bacon strips to the door handles of the Central Mosque in Edinburgh and threw some strips inside were sentenced to several months in prison in 2014 (BBC 2014). Although the attackers, the court, and the Muslim community certainly hold rather different understandings of sacredness, they shared the judgement that the intention of the attack was to symbolize an offensive, abusive act, in spite of the small damage it caused. 


\section{Early Examples of Sharing and Polemics}

Against the background of intolerant acts and discourses, a word about the history of inter-religious sharing seems in order. Elizabeth Fowden (1999), who specializes in the material cultural of the Eastern Mediterranean, mentions three sites-the oak of Mamre in Hebron, the Umayyad Mosque in Damascus, and a complex in Rușāfa-as early examples of shared holy places.

According to tradition, the oak of Mamre was seen as the place where Abraham built an altar for God and where Yahweh and two angels appeared to him and his wife Sarah. When the two offered hospitality to the three strangers, the visitors foretold Sarah's conception of a son. The ecclesiastical historian Sozomen (d. 450) described festivities in which not only Jews and Christians took part but also "the Phoenicians and the Arabians" (Fowden 1999, 127). By building a church 150 years before Sozomen's report, the Christians tried to monopolize the place but were not successful at that time (ibid., 128).

In Damascus, Christians and Muslims commonly used a monumental basilica, dedicated to St. John the Baptist and built on the site of a former temple of Jupiter as well as an Aramean temple, for more than 70 years (from 635 to $706 \mathrm{CE}$ ). According to Muslim historians al-Balādhurī (d. 892) and Ibn 'Asākir (d. 1176), the Umayyad caliph al-Walīd I commissioned the construction of a new mosque in 706, which took about a decade. Part of this appropriation was also the "discovery" of John the Baptist's head by the caliph in a subterranean chapel, "which became part of the foundational myth of the mosque" (ibid., 133).

The third example, the shrine of St. Sergius at Rușāfa, was the most celebrated Christian Arab pilgrimage destination of late antique Syria and Mesopotamia (ibid., 134). In the eighth century CE, architects built a mosque that shared the courtyard and its stoa with the city's main church, which housed the martyrium of St. Serigus" (ibid., 135). The architecture, combining the mosque with the church, not supplanting it, made the participation of Muslims in the cult of St. Sergius possible.

In these three examples, sharing the same place means the "maintenance of separateness" (ibid., 127) of ritual. Sharing was, however, not limited to sacred places, shrines, and buildings, but also applied to rituals and saints than can accommodate different layers of meanings. Scholar of Jewish religion Alexandra Cuffel (2005), citing thirteenth- to sixteenth-century reports, travelogues, and biographies, draws attention to Jewish, Christian, and Muslim women who were said to donate lamps, oil, candles, money, and food to the shrines of holy men and women as well as to pilgrims. In these reports, shared rituals between "Turks, Moors, and Christians" (ibid., 408) are mentioned for the Milk Grotto in Bethlehem and al-Mațariyya close to Cairo. Coming 
to the Milk Grotto, people of all faiths, especially expectant mothers, drink pulverized dust dissolved in water as a cure for barrenness and difficulties in childbirth or nursing. According to a tradition, a drop of milk of the nursing Mary fell on the floor and changed its colour to white. Al-Mațariyya is said to be the place where Mary, Joseph, and the Child stopped under a tree on their flight to Egypt; suddenly a spring of water sprung up. The eyewitnesses of festivities in this place mention women of different faiths bathing in the water and bathing their children.

Moreover, Muslim chroniclers since the eleventh century attest to common prayers and processions in times of disaster, such as earthquakes and drought; they give the impression that "the inclusion of all types of human beings seems to have been an essential part of the ceremonies" (Cuffel 2013, 127). Under Mamluk rule in Egypt and Syria, public prayers for rain (istisqā') were performed as state-sponsored intercessory processions to a holy place, including the participation of the caliph, "the chief qãdī on foot among masses of students, poor and Sufis" as well as "the Jews and the Christians with their scriptures" (ibid., 126), according to a source of $1450 \mathrm{CE}$. A report from the late fourteenth century about a prayer procession outside of Damascus mentions that "the ritual begins with the Muslim people's fast, prayer at the mosque, a special gathering, and prayers at night" (ibid., 127), and when the Muslims leave the mosque, "Jews, Samaritans, and Christians join their Muslim neighbours, praying with them" (ibid.).

A prominent figure among shared saints is Khidr, "who is identified in the Muslim tradition as the unnamed companion of Moses who holds the secret to immortal life (Qur'an 18:60)" (Barkey 2014, 50). He is "often confused (or fused)" (Fowden 1999, 133) with the Christian saints Sergius and George and also venerated by Șūfīs, Zoroastrians, Yazidis, Alevis, and Alawites. In folk religion, Saint George and Khidr are both understood as dragon-slaying saint heroes, while the Islamic tradition also knows that Khidr and the Prophet Elijah meet every year (for more, see Franke 2000). The mixture of these figures is connected to a spring festival called Hidrellez, which is not only widespread from Anatolia over the Balkans to Crimean Tatars, but was also recognized as a feast day in the official contract between the city-state of Hamburg and the Alevi community in 2012. In this volume, Méropi Anastassiadou-Dumont comes back to the fascinating figure of Khidr and Hıdrellez in her discussion of holy places in Istanbul.

Sharing places, rites, and saints was also accompanied by religious polemics, prejudices, and imaginary tales, which shows once again that inter-religious practices went hand in hand both with communality and demarcation. In fact, our knowledge about cross-religious and cross-confessional practices in the distant past stems, to some degree, from polemics written by religious scholars who frown upon such practices or oppose them. Because the pilgrimage to shrines, the veneration of 
holy women and men, and prayers for healing or help in existential situations were often associated with women's pious activities and cross-faith sociability in all three traditions, scholars have described them as folk and women's religion. Theological polemicists often argued against the mixing of both religions and gender. As Cuffel (2005) shows, some Muslim scholars explicitly associated women's visible participation in such circumstances with non-Muslim practices, innovation (bida'), and immorality; thus, they also tried to shame their male co-religionists and stimulate them to behave "manly." Several Muslim scholars, like Ibn Taymiyya (d. 1328) and Ibn al-Hajj (d. 1336), abhorred that Muslim women bathed their children together with non-Muslim women at Mațariyya, which would allow non-Muslim women to look at the body of a Muslim woman-a "scandalous matter" these scholars declared forbidden (ibid., 410). Even scholars who defended the practices of visiting saints' shrines "felt obliged to address women's participation as a separate issue" (ibid., 412) and contrasted "the masculine ideal of knowledge and control...to women's emotionalism" (ibid., 413), thus denigrating but not condemning such customs. For European Christian and Jewish authors, the participation of women was secondary; their polemics were directed more at the blurring of religious boundaries than at gender difference. An example that unites the blurring of religious boundaries with a polemic undertone is the story-told by the Jewish rabbi and traveller Moses b. Mordechai Bassola (d. 1560)_about a Muslim woman who wanted to pick almonds from a tree on a Jewish saint's grave without asking permission from the saint, against the advice of another woman (Cuffel 2005, 407f.). The woman fell from the tree and broke all of her limbs "until she dedicated the gold that was on her hand" (ibid., 408). After that, other trees were also dedicated, and sixty years after the Muslim woman's act, a field of four hundred olive trees "sacred to the saint" (ibid.) had resulted from her accident.

The real or imagined Jewish and Muslim veneration of the Virgin Mary was a source of wonder and a rhetorical weapon for Christian authors of the twelfth and thirteenth centuries (Cuffel 2003, 37). In various tales, polemicists underlined their supremacy of Christianity in different ways, depending on whether they judged Muslim or Jewish encounters with Mary or whether the Christian authors were located in areas of Europe where Muslims and Jews were relatively near or relatively distant (ibid., 37). Generally, "the Virgin Mary fought and won her own battles with the Muslims not with argumentation or swords, but with miracles" (ibid., 40). Often, these stories portray Mary as willing to assist Muslims and help them in spite of their opposition to Christianity (ibid., 41). The difference is that "in most stories originating from Latin Europe, such encounters almost invariably resulted in the Muslims' conversion to Christianity" (ibid., 42) as soon as the Muslims admitted their love of the Virgin. In Christian narrations from the Eastern Mediterranean, similar plots do not result in the Muslims' conversion. 
Mary's miraculous interventions on behalf of Muslims were rather seen as a fulfilment of the prophecy that "all generations shall call me blessed" (Luke 1: 48). Thus, the Muslims' and "sinners'" veneration of Mary gained importance because of their status as outsiders to Christianity.

The Christian stories about Jewish encounters with Mary developed against a different backdrop, since Mary does not appear in the Jewish scriptures and is depicted as a figure doomed to give birth to a false messiah in medieval extra-biblical writings. As the Christian stories can thus be read as a reaction to the Jews' well known and "longstanding rejection of Christianity" (ibid., 58), Jews only have the choice between conversion, death, and condemnation to hell. The stories, in which Mary intervenes and takes revenge against recalcitrant Jews, easily outnumber similar stories with Muslims: "That Jews regularly needed Mary despite their vehement rejection of her was perhaps the strongest demonstration of Christianity's power" (ibid., 59).

\section{Non-Sharing as Part of Inter-Faith Practices}

Cross-faith polemics, prejudices, nationalist imaginaries, and the model of "antagonistic tolerance" can nurse doubts as to the degree to which inter-religious sharing is possible. Yet, the framing of (peaceful) practices of sharing versus the (violent) tendency of nonsharing along the lines of Hayden's (2002) argumentation not only rests on a dichotomy but also on one that is false.

In a recently edited volume, Darieva et al. (2018, 9f.) have drawn attention to the fact that the assumption that non-sharing "equals hostility or...hinders friendly coexistence" is not necessarily correct; nor does cohabitation "necessarily lead to sharing, collaboration or religious mixing." Drawing on earlier research (Weiner 1992; Hauschild 2003, 2008), the anthropologist Florian Mühlfried (2018, 151f.) stresses that preventing objects from free circulation or restricting access to shrines "may well form the backbone of economically and socially interacting with other people." By arguing against the anthropological "fetish of connectivity" (Pedersen 2013), Mühlfried (ibid., 152) holds that the non-sharing of practices, places, or objects can discharge potential tensions in society and "may contribute to good social relations by avoiding conflicts and sustaining autonomy." Thus, not sharing can create "cultural reserves" that are withdrawn not only from general use but also from contestation and commodification; these "cultural reserves" can minimize risks for minorities and enhance their potential of belonging to society. In this sense, Mühlfried argues that the small Jewish community of Racha in Georgia developed a sense of belonging to place and society by not sharing Christian or Georgian sacred sites. In the joint history of the Jewish and Christian 
population of Racha, a shared sense of mutual understanding and conviviality "goes alongside a strict division of sacred spaces," Mühlfried (ibid.) argues. By not sharing places with the majority, Georgian Jews could not and did not make claims to the majority's territory, while they preserved their own; the Christian majority in turn protected the Jewish synagogue against destruction in Soviet times, when they were unable to save their churches which were considered symbols of the ancient regime. "It has been precisely this religious difference, manifested in landscape, which fostered a friendly mode of coexistence" (ibid., 169).

While Mühlfried interprets the act of "not sharing the sacred" as a "cultural reserve," Silvia Serrano (2018) draws attention to a different example of nonsharing - a multi-religious complex whose mode of existence is based on "sharing the not-sacred." Inaugurated in 2012, the complex, known as Rabati in Southern Georgia, bordering Turkey, consists of a mosque, a madrasa, an Orthodox church, a Romantic pavilion, as well as boutiques, restaurants, and a hotel. Nearby, there are also Turkish baths, two synagogues, and an Armenian and a Catholic church. The state-sponsored restoration-the only one including non-Orthodox religious buildings in Georgia-is designed to represent the living history of the religiously diverse border region of Georgian and is meant to attract international tourists to a "symbol of tolerance," according to self-promotion which draws on a pluralistic and multicultural vision of Georgia (ibid., 212). This celebration of multi-culturalism is achieved by a de-sacralisation of the cultural heritage, "by banning religious practice in all the sites located in Rabati" (ibid., 215). Thus, the state implicitly reinforces the idea that coexistence of various religions favours conflict and that there would be conflicts if the mosque were opened for worship. Although the restoration of the mosque was deemed necessary, it was not even possible to set up a crescent. Any criticism by Turkish diplomats regarding changes introduced to the original architecture were considered an illegitimate intervention of a foreign power. Thus, the mosque was deprived of its local history and Georgian characteristics and turned into "a generic Islamic building" with elements from the Moorish architecture of the Alhambra and the Dome of Rock in Jerusalem. The dome of the mosque has been gilded to symbolize a "New Jerusalem"with a mosque, a church, and a synagogue side by side (ibid., 220). Yet, the presence of Muslims and Jews in the discourse of multi-culturalism contrasts with their absence in the town (ibid.). Though representing a multi-religious site, Rabati's version of Disneyland is certainly no place of sharing the sacred.

The anthropologist Will Tuladhar-Douglas (2012) has drawn attention to another facet of non-sharing: the case of the non-participation of resident Tibetans in a procession that ideally unites all communities in the Nepalese town of Pharping in the Kathmandu valley. The Newars, the indigenous population of the valley, who 
have achieved a complex synthesis of Buddhism and Hinduism, annually organize a procession of Vajrayoginī, the image of a Tantric Buddhist female Buddha, from her shrine to the town. The procession has a tradition of more than one thousand years and draws the residents of Pharping together for a festival lasting three days (ibid., 65). As the event ideally invites all members of local religions to celebrate a Pharping identity, the refusal of the so-called Tibetan Buddhists, who perceive the procession as a Hindu ritual, puts to test the strategies of a mixed community to cope with diversity without exclusion. Tuladhar-Douglas (2012) explains this non-participation as a "complementary process" (ibid., 62) in a region where intercommunal collaboration in ritual life is a rule and "worshippers collude in ignoring potentially divisive behaviour." Although Tibetan Buddhists opt out, the Pharpings, who practice inclusivism, tend to overlook or deny this fact in order to sustain a social fabric that is based on disavowing exclusivist behaviour (ibid., 73).

An example similar to Mühlfried's study of Georgian Jews, yet with another nuance of non-sharing, is Robert Langer's (2008) inventory of Zoroastrian shrines in modern Iran. As the vast majority of the one hundred shrines that Langer has documented is not shared, they appear to be a "cultural reserve" in Mühlfried's sense. However, Langer also found one shared Zoroastrian-Muslim shrine (ibid., 462-467) and one ZoroastrianJewish twin shrine (ibid., 637-640). On the one hand, he interprets these two shrines as left over from a long history of interaction and sharing (ibid., 180-196); on the other hand, it is clear that the vast majority of shrines are not-or no longer-shared sacred places. Thus, we can firstly conclude that there are exceptions to the rule, in this case to not sharing. Secondly, even the mere existence of so many shrines after approximately 1,400 years of Muslim rule expresses a form of cohabitation that contributes to a multireligious landscape extending well beyond the main Zoroastrian settlement areas in Iran. Before Langer's inventory, the maximum number of Zoroastrian shrines in Iran had been estimated at 25 (Langer 2008, 48). His field research has not only disproved this estimation, but has also shown the wide range of Zoroastrian sites, from private shrines to veritable pilgrimage centres.

\section{This Volume: Changing Practices, Changing Landscapes}

As especially the last examples of partial non-sharing in multi-religious settings show, multi-faith encounters cannot be reduced to a narrow understanding of sharing the sacred or a dichotomy between sharing and non-sharing. They include asymmetrical relations as well as forms of non-sharing, and they can comprise ideals of inclusivism, 
deviating practices, and conflicting claims. The examples of prayer rooms in nonreligious environments; the long history of shared sites, practices, and polemics; the consecutive sharing of buildings between different faiths; and the cross-religious veneration of saintly figures-all of these phenomena open up a variety of perspectives on multi-faith encounters and spatial arrangements that exceed the dichotomy of sharing and not sharing. They hint at the long historical trajectories of holy sites, their embeddedness in changing multi-religious landscapes, and the multiplicity of multifaith practices. Therefore, these examples not only bind together the distant past with contemporary concerns but also show that the actors of inter-faith encounters may share or not share and differently interpret, ignore, or lay exclusive claim to what they believe is sacred.

Against the background of this vibrant field of research, the present special issue of Entangled Religions has emerged from a conference about "Shared Sacred Places and Multi-Religious Space" that took place at the Leibniz Institute of European History (IEG) in Mainz in September 2016. As the title of the conference indicates, a main interest was to re-think the relation between place and space and between different religions. The conference took place in the framework of the IEG focus topic "Europe from the Margins," which also included a lecture series on processes of marginalization and exclusion with regard to social and religious minorities within and beyond Europe. This background explains the range of topics in this special issue to a certain degree, because the conference had the aim to de-centre established notions of Europe and religion and understand them in their multi-dimensionality. While cross-faith practices are a worldwide phenomenon, the main geographical focus of the following articles is on southeastern Europe and the Mediterranean with their spatial extensions to Asia. Proceeding from here, the contributions in this volume understand multi-faith practices as embedded in local arrangements as well as in larger multi-religious landscapes, thus taking account of the interconnection between the local and the global and paying attention to the micro and macro levels of analysis.

Méropi Anastassiadou-Dumont raises a topic not present so far in the canon of research literature on sacred places and pilgrimage-formerly Christian places in the wider Constantinople/Istanbul region increasingly taken over by (nominal) Muslims since the second half of the twentieth century. In her contribution "Sacred Spaces in a Holy City. Crossing Religious Boundaries in Istanbul at the Turn of the Twenty-First Century," she suggests that shared cults must have existed for some time, although the literature of the nineteenth and early twentieth centuries lacks such information for various reasons. She then draws attention to the Greek word ayazma that is used in Turkish to name holy water sources and notes that today, the ayazmas, which were a Greek Orthodox specificity in Istanbul, attract mainly Muslim pilgrims, while Greeks 
tend to abstain from showing up with "others." The most famous Muslim pilgrimage to a Christian ayazma, taking place every year, leads to the Byzantine monastery of St. George Koudounas in Büyükada (the Princes Island). Although Orthodox presence was very strong before the 1990s, Greek absence is also visible in several other places, as Anastassiadou-Dumont shows. Her explanation is that the interreligious field remains highly fluctuating and that, although the Turkish state desires, organizes, and controls interreligious sharing, the demographic shift and political developments may have a different effect.

In his contribution "A Muslim Holy Man to Convert Christians in a Transottoman Setting: Approaches to Sarı Saltuk from the Late Middle Ages to the Present," Stefan Rohdewald wonders to what degree Sarı Saltuk, a legendary warrior-saint assumed to have died in 1297/98, really represents an inter-religious figure. Although held in high esteem by the Bektashi Order and claimed by Christians as St. Spyridon, St. Nicholas, or St. Naum, the available sources rather point at conflicting claims and interpretations than at inter-religious veneration that moreover seems to have steadily decreased over the centuries, if it ever existed. Sifting through the hagiographic literature, Rohdewald stresses the high mobility that was accredited to this warrior-saint, who presumably wandered from Arabia over Anatolia and the Balkans to Gdansk. Even after his departure, this mobility was not interrupted, as seven coffins, Sarı Saltuk's body in each of them, were sent out to the Kings of Moscow, Poland, Bohemia, Sweden, Adrianople, and Moldova as well as to the ruler of Dobruca, all of whom had asked for his remains. Since a wide extension of Sarı Saltuk's area of action beyond the borders of the Ottoman Empire can be observed especially since the seventeenth century, Rohdewald doubts whether the figure and its sanctuaries can be understood as transreligious phenomena, instead underlining their trans-regional and trans-Ottoman character. As Sarı Saltuk's ante and post mortem mobility covered the Ottoman Empire, Poland-Lithuania, Muscovy, and the Crimean Khanate, it described a region "intertwined through extensive, mutually claimed borderlands." Thus, Sarı Saltuk's inter-religiosity seems to represent a case in which a figure is venerated "commonly," but not "in common," as Glenn Bowman succinctly puts in his contribution.

In "Spirit of Place and Nation Building: Kosovo and Bosnia from Imperial to PostCommunist Times," Tanja Zimmermann compares the spirit of place, the genius loci, of the Serbian and the Bosnian legend of origin and its meaning for nation building. The Serbian nationalist narrative reactivates the legend of the Serbian defeat against the Ottomans in the Battle of Kosovo on "the Field of Blackbirds" (Kosovo polje) in 1389. This event was recounted not only by local actors but also by European travellers, artists, and architects in the course of nation building in the nineteenth century. The legend turned into a "natural" Serbian myth and was embodied by Gazimestan, the memorial 
place at the core of the Field of Blackbirds, where a memorial tower was erected in 1953. As this place has belonged to the autonomous Republic of Kosovo since 2008, the memorial today is "fenced and monitored by cameras, to prevent it from being destroyed by Albanians." The foundation myth for a Bosnian nation lacked a similar location. As Bosnia became a Habsburg protectorate after 1878, the Austro-Hungarian project aimed at creating common ground for Muslims, Jews, Catholics, and Orthodox Christians by focusing on the pre-Ottoman Bogomils, who surrendered neither to Rome nor to Constantinople and followed Manichaeism in spite of Christendom, but later turned to Islam. Lacking a spirit of place, the National Museum in Sarajevo, founded in 1888 , collected traces from the past in a scientific manner. "In the garden, a large collection of Bogomilian grave steles (stećci), brought from different scattered places in Bosnia, was displayed." In Yugoslavia of the communist era, after the break with the UdSSR, the Bogomils were also presented as predecessors of Tito's "third way" beyond Soviet communism and Western capitalism. However, Zimmermann's comparison between the two myths shows that the Bogomil legend was doomed to fail because it lacked a location and thus the spirit of place, whereas the rivalling Serbian myth was based on a strong genius loci.

In his article "Shared Shrines and the Discourse of Clashing Civilisations," Glenn Bowman sums up his long experience, thirty-five years of research, with Muslim-Christian cohabitation at various places and in different regions. He outlines the possibilities and limits of sharing the sacred against the background of wider intellectual and political developments that favour "groupism" and "identitarianism" and often tend to exclude Muslims. Discussing three different case studies of MuslimChristian sharing - the Monastery of Sveti Bogoroditsa Prechista near Kicevo, North Macedonia; the Church of the Holy Sepulchre in Jerusalem; and the site of Sveti Nikola/ Hadir Bābā in Makedonski Brod, North Macedonia-, he highlights the differences between these places. Bowman argues that the difference between place and space is key to understanding the emergence of antagonism in shared sites. Place forms a site of inhabitance and concrete interaction, while space can hold different entities that have no relation. When different groups share a place, they are forced to accommodate to each other's presence. When, however, two or more communities try to construct and inhabit place exclusively, accommodation becomes impossible. When places are transformed into exclusive properties, sharing and mixing turn contentious and any conflict can be read as a sign of a wider irresolvable antagonism. For Bowman, then, the discursive framing-exemplified by the "clash of civilisations" discourse-is a main point that transforms shared sites into arenas of struggle.

In "Digressions on Polytropy: An Exploration of Religious Eclecticism in Eurasia," Dionigi Albera employs the concept of "polytropy" that has been introduced by 
anthropologist Michael B. Carrithers in the field of the study of religion. As scholars generally accept that polytropic forms of religious life are widespread in South Asia, Albera discusses various examples of religious eclecticism and fluidity in China, India, and Japan and argues that Christians and Muslims in Asia also show polytropic forms of worship. Therefore, he sees no reason not to transfer the notion of polytropy to the Mediterranean region as well, in which monotheistic beliefs dominate. Drawing on the manifold studies on religious sharing, he argues that "Mediterranean religious pluralism seems to produce effects comparable to those observed in Asia." Arguing against the "religious congruence fallacy" that assumes that an individual's religious beliefs, attitudes, and behaviour are congruent and stable, Albera proposes to generally rethink religious diversity along the differentiation between polytropy-in the sense of multiplicity and versatility-and monotropy-in the sense of unity and uniformity. While polytropic tendencies are constitutive elements of religiosity, monotropic propensities occupy the centre of the stage in any religious traditions and assure the continuity and stability of any religious tradition. However, these concepts do not describe absolute fixities but tendencies, since "the religious specialists, who are the main bearers of the religious system, may often accommodate lay people's polytropic trends, which they accept and also encourage, even if they do not personally adhere to these forms of religiosity." The concept of "polytropy" can help us to better grasp the practical modality of doing religion, although-or because- "monotropic" tendencies hold a hegemonic position in the religious landscapes of the so-called "world religions," according to Albera.

Manfred Sing deals with the places and spaces ascribed to Islam in two interrelated contributions. In "Where Do the Multi-Religious Origins of Islam Lie? A Topological Approach to a Wicked Problem," he critically analyses the academic debate about the location of the origins of Islam. In the last few decades, revisionist scholarship has increasingly cast doubt on Mecca as the birthplace of Islam and attempted to relocate the origins of Islam to the North of the Arabian Peninsula. A relocation would better explain the manifold hints at Biblical material in the Qur'ān and the minor role of pre-Islamic Mecca. Mainstream scholarship, however, clings to the differentiation between Meccan and Medinan revelations, although the Qur'ān rarely mentions any places. Sing takes both revisionist and traditional scholarship to task when he proposes to understand the social and historical production of Mecca as a gradual process intertwined with the emergence of Islam. He also holds that the treatment of various pagan, Jewish, Christian, and other religious elements in the Qur'ān and early Islam is connected to the religious diversity that is characteristic for Islam as well as for the landscapes in which Islam emerged. This argument forms the bridge to the second article, "Towards a Multi-Religious Topology of Islam: The Global Circulation 
of a Mutable Mobile," in which Sing argues that it is impossible to understand the history of Islam without considering its internal and external diversity. Therefore, he proposes the concept of a multi-religious topology for the study of Islam. Drawing on the discussion about the spatial turn in the humanities, he argues that it is necessary to distinguish between the argument that our ideas about space are socially produced and the argument that space is socially produced. Thus, he critically revisits different academic ways through which Islam is inscribed onto space and history, and argues that approaches that speak of "Islamic space" homogenize Muslims and obliterate nonMuslim peoples. In response, he argues that from early on, Islam was located in a transreligious and transcultural space in which ideas about Islam circulated, took shape and were discarded. Sing shows how Muslim and non-Muslim scholars discussed common reference points-the role of Sufis, Jews, and Christians under Muslim rule-and how arguments about Islam also informed European debates about religious tolerance, the treatment of Native Americans, and the abolishment of slavery. The manifold interconnections created a common space for both "Europe" and "Islam," although they were mostly conceptualized as antagonistic entities.

\section{Acknowledgments}

I thank the Leibniz Institute of European History in Mainz for funding the conference on "Shared Sacred Places and Multi-Religious Space" in 2016 that brought together researchers with different disciplinary backgrounds. The idea for the present volume goes back to the insights, challenges, and perspectives discussed during three days of fruitful scholarly exchange. I am grateful to the anonymous reviewers, whose critical comments helped much to improve the volume as a whole as well as the individual articles. Special thanks goes to Julia Reiker and Maren Freudenberg for carefully copyediting all articles in this special issue of Entangled Religions.

\section{Literature}

Albera, Dionigi. 2008. “'Why Are You Mixing what Cannot be Mixed?' Shared Devotions in the Monotheisms." History and Anthropology 19 (1): 37-59.

Albera, Dionigi, and Maria Couroucli, eds. 2012. Sharing Sacred Spaces in the Mediterranean: Christians, Muslims, and Jews at Shrines and Sanctuaries. Bloomington: Indiana University Press. 
Arera-Rütnek, Tobias. 2017. Transformation von Moscheen zu Kirchen auf der Iberischen Halbinsel. Petersberg: Micheal Imhof Verlag.

Augé, Marc. 1995. Non-Places. Introduction to an Anthropology of Supermodernity. London: Verso.

Barkan, Elazar, and Karen Barkey. 2014a. "Introduction." In Barkan and Barkey 2014b, 1-31.

_- - ed. 2014b. Choreograhies of Shared Sacred Sites. Religion, Politics, and Conflict Resolution. New York: Columbia University Press.

Barkey, Karen. 2014. "Religious Pluralism, Shared Sacred Sites, and the Ottoman Empire." In Barkan and Barkey 2014b, 33-65.

BBC. 2014. "Pair Jailed for Edinburgh's Central Mosque Bacon Attack." June 20, 2014. https://www.bbc.com/news/uk-scotland-edinburgh-east-fife-27941589.

Beinhauer-Köhler, Bärbel, and Christian Meyer. 2015. “In Bewegung. Gebetsräume für Juden, Christen und Muslime am Frankfurter Flughafen.“ In Beinhauer-Köhler, Roth, and Schwarz-Boenneke 2015, 195-212.

Beinhauer-Köhler, Bärbel, Mirko Roth, and Bernadette Schwarz-Boenneke, ed. 2015. Viele Religionen - ein Raum?! Analysen, Diskussionen und Konzepte. Berlin: Frank \& Timme.

Bowman, Glenn. 2002. "Comments." Current Anthropology 43 (2): 219-220.

- - , ed. 2012. Sharing the Sacra. The Politics and Pragmatics of Intercommunal Relations around Holy Places. New York: Berghahn Books.

Bryer, Anthony. 1979. "The Late Byzantine Monastery in Town and Countryside." Studies in Church History 16: 219-241.

Couroucli, Maria. 2012. "Sharing Saced Places - A Mediterranean Tradition." In Albera and Couroucli 2012, 1-9.

Cuffel, Alexandra. 2003. “'Henceforward all generations will call me blessed': Medieval Christian Tales of Non-Christian Marian Veneration." Mediterranean Studies 12: 37-60.

- - . 2005. "From Practice to Polemic: Shared Saints and Festivals as 'Women's Religion' in the Medieval Mediterranean." Bulletin of the School of Oriental and African Studies 68 (3): 401-419.

- - . 2013. "Environmental Disasters and Political Dominance in Shared Festivals and Intercessions among Medieval Muslims, Christians, and Jews." In Muslims and Others in Sacred Space, edited by Margaret Cormack, 108-146. Oxford: Oxford University Press.

Darieva, Tsypylma, Thede Kahl, and Svetoslava Toncheva, eds. 2017. Sakralität und Mobilität im Kaukasus und in Südosteuropa. Wien: Verlag der Österreichischen Akademie der Wissenschaften. 
Darieva, Tsypylma, Florian Mühlfried, and Kevin Tuite, eds. 2018. Sacred Places, Emerging Spaces. Religious Pluralism in the Post-Soviet Caucasus. New York: Berghahn Books.

Eliade, Mircea. (1959) 2008. Das Heilige und das Profane: Vom Wesen des Religiösen. Köln: Anaconda.

Fowden, Elizabeth Key. 1999. "Sharing Holy Places." Common Knowledge 8 (1): 124146.

Franke, Patrick. 2000. Begegnung mit Khidr. Quellenstudien zum Imaginären im traditionellen Islam. Stuttgart: Franz Steiner Verlag.

Gieryn, Thomas F. 2000. "A Space for Place in Sociology." Annual Review of Sociology 26: 463-496.

Groß, Gisela. 2000. “Multireligiöse Räume." Kunst und Kirche 63 (2): 66-71.

Grimes, Ronald L. 2014. The Craft of Ritual Studies. Oxford: Oxford University Press.

Hauck-Hieronimi, Gerda. 2015. “Acht Weltreligionen-ein Dach-ein gemeinsamer Betrieb. Haus der Religionen-Dialog der Kulturen in Bern." In BeinhauerKöhler, Roth, and Schwarz-Boenneke 2015, 163-175.

Hasluck, Frederick W. 1929. Christianity and Islam under the Sultans, 2 vols, edited by Margaret M. Hasluck. Oxford: Oxford University Press.

Harris, Jonathan, Catherine Holmes, and Eugenia Russell, eds. 2012. Byzantines, Latins, and Turks in the Eastern Mediterranean World after 1150. Oxford: At the Clarendon Press.

Hauschild, Thomas. 2003. Magie und Macht in Italien: Über Frauenzauber, Kirche und Politik. Gifkendorf: Merlin-Verlag.

-_-. 2008. Ritual und Gewalt. Frankfurt am Main: Suhrkamp.

Hayden, Robert M. 2002. "Antagonistic Tolerance. Competitive Sharing of Religious Sites in South Asia and the Balkans." Current Anthropology 43 (2): 205-219.

- - . 2015. "Intersecting Religioscapes in Post-Ottoman Spaces: Trajectories of Change, Competition and Sharing of Religious Spaces." In Shared Spaces and their Dissolution: Practices of Coexistence in Cyprus and Elsewhere, edited by Rebecca Bryant, 59-85. New York and Oxford: Berghahn.

Hayden, Robert, Tuğba Tanyeri-Erdemir, Timothy D. Walker, Aykan Erdemir, Devika Rangachari, Manuel Aguilar-Moreno, Enrique López-Hurtado, and Milica BakićHayden. 2016. Antagonistic Tolerance: Competitive Sharing of Religious Sites and Spaces". London: Routledge.

Huntington, Samuel P. 1996. The Clash of Civilizations and the Remaking of World Order. New York: Simon \& Schuster.

Jonas, Marin. 2008. “Interreligiöse Räume: Miteinander oder nebeneinander?” In Justnik and Feldhoffer 2008, 12-13. 
Justnik, Herbert. 2008. "Einleitung." In Justnik and Feldhoffer 2008, 7-8.

Justnik, Herbert, and Juliane Feldhoffer, eds. 2008. Places of Worship: Andreas Duscha. Interfaith prayer rooms at airports; Begleitbuch und Katalog zur Ausstellung im Österreichischen Museum für Volkskunde, 17.09.-16.11.2008. Wien: Metroverlag.

Kletke, Daniel. 2000. "Der Meditationsraum bei den Vereinten Nationen in New York." Kunst und Kirche 63 (2): 98-99.

Knott, Kim. 2005a. The Location of Religion: A Spatial Analysis. London: Equinox.

-_- 2005b. "Spatial Theory and Method for the Study of Religion." Temenos 41 (2): 153-184.

- - . 2009. "From Locality to Location and Back Again: A Spatial Journey in the Study of Religion." Religion 39 (2): 154-160.

Kölbl, Alois, and Andreas Duscha. 2010. “Interreligiöse Gebetsräume auf Flughäfen. Alois Kölbl im Gespräch mit Andreas Duscha." Kunst und Kirche 73 (2): 27-29.

Krstic, Tijana. 2013. “The Ambiguous Politics of 'Ambiguous Sanctuaries': F. Hasluck and Historiography on Syncretism and Conversion to Islam in $15^{\text {th }}$ and $16^{\text {th }}$ Century Ottoman Rumeli." In Archaeology, Anthropology and Heritage in the Balkans and Anatolia: The Life and Times of F.W. Hasluck, 1878-1920, vol. 3, edited by David Shankland, 247-262. Istanbul: The ISIS Press.

Kuschel, Karl-Josef. 2010. "Multireligiöse Andachtsräume - eine Problemanzeige. Theologische und interreligiöse Perspektiven." Kunst und Kirche 73 (2): 5-11.

Langer, Robert. 2008. Pīrān und Zeyāratgāh: Schreine und Wallfahrtsstätten der Zarathustrier im neuzeitlichen Iran. Leuven: Peeters.

Limor, Ora. 2007. "Sharing Sacred Space: Holy Places in Jerusalem between Christianity, Judaism and Islam." In In Laudem Hierosolymitani: Studies in Crusades and Medieval Culture in Honour of Benjamin Z. Kedar, edited by Iris Shagrir, Ronnie Ellenblum, and Jonathan Riley-Smith, 219-231. Aldershot: Ashgate.

Löffler, Klara, and Herbert Nikitsch. 2008. "Ein-/Blicke: Die interreligiösen Räume in München und Wien." In Justnik und Feldhoffer 2008, 14-16.

Mühlfried, Florian. 2018. "Not sharing the Sacra." In Darieva, Mühlfried, and Tuite, 2018, 150-176.

Nagel, Alexander-Kenneth. 2015. “Kontaktzone oder Spannungsfeld? Multireligiöse Räume in religionssoziologischer Perspektive." In Bärbel Beinhauer-Köhler, Roth, and Schwarz-Boenneke 2015 2015, 35-54.

Norwich, John J. 2011. A History of England in 100 Places. From Stonehenge to Gherkin. London: John Murray. 
Pedersen, Morten A. 2013. "The Fetish of Connectivity." In Objects and Materials. A Routledge Companion, edited by Penny Harvey et al., 197-207. London: Routledge.

Shankland, David, ed. 2013. Archaeology, Anthropology and Heritage in the Balkans and Anatolia: The Life and Times of F.W. Hasluck, 1878-1920, 3 vols. Istanbul: The ISIS Press.

Serrano, Silvia. 2018. "Sharing the Not-Sacred. Rabati and Displays of Multiculturalism." In Darieva, Mühlfried, and Tuite, 2018, 203-225.

Smith, Jonathan Z. 1987. To Take Place: Toward a Theory of Ritual. Chicago: University of Chicago Press.

Spiegel, Andreas. 2008. "Der unbeliebte Raum und Räume der Beliebigkeit." In Justnik and Feldhoffer 2008, 17-19.

Tuladhar-Douglas, Will. 2012. "The Work of Mending: How Pharping People Manage an Exclusivist Response to the Procession of Vajrayogini." In Bowman 2002, 61-78.

Vogler, Bernard. 2000. "Simultaneum." In Theologische Realenzyklopädie Online, TREonline, vol. 31, 280-283.

Weiner, Annette B. 1992. Inalienable Possessions: The Paradox of Keeping-WhileGiving. Berkeley: University of California Press.

Weltecke, Dorothea. 2012. "Multirreligiöse Loca Sancta und die mächtigen Heiligen der Christen." Der Islam 88: 73-95. 